\title{
IN VITRO STUDIES ON CALLUS INDUCTION IN BOTH VEGETATIVE AND GENERATIVE PARTS IN ALSTROEMERIA FOR FURTHER APPLICATION TO TRANSFORMATION
}

\author{
J.-B. Kim, M. de Jeu, K.J.J.M. Raemakers, E. Jacobsen and R.G.F. Visser \\ Laboratory of Plant Breeding, \\ The Graduate School of Experimental Plant Sciences, \\ Wageningen University, P.O.BOX 386, 6700 AJ, Wageningen, \\ The Netherlands
}

Keywords: Compact callus, friable callus, monocot, regeneration, transformation

\begin{abstract}
$\underline{\text { Abstract }}$
We compared both vegetative and generative parts of Alstroemeria in friable embryogenic callus induction, and subsequent production of somatic embryos and regeneration of plants because there exist only a few protocols with low efficiency for application to transformation. Nodal parts of the plant showed the best performance in callus induction, production of somatic embryos and regeneration as compared to internodes and all seven generative parts tested. Thus, it can be concluded that the nodal explants can be used as a source for transformation in combination with the MS medium containing $1 \mathrm{mg} / \mathrm{l}$ 2,4-D, $0.25 \mathrm{mg} / \mathrm{l} \mathrm{BAP,} 3 \%$ sucrose (w/v) and $0.75 \%(\mathrm{w} / \mathrm{v})$ microagar for the production of a high level of compact callus and somatic embryos. In the future, more research will be needed on the acceleration of the plant production process from somatic embryos, to use this system in an optimised way for transformation experiments.
\end{abstract}

\section{$\underline{\text { 1.Introduction }}$}

In Alstroemeria, only a few reports on callus induction and regeneration have been published, whereas the knowledge in these fields is considerably important for further application of Alstroemeria transformation (Ziv et al., 1973; Gonzalez-Benito and Alderson, 1992; Hutchinson et al., 1994; Van Shaik et al., 1996; Lin et al., 2000a). Most of these reports did not show the ideal results for the next step to genetic modification. Furthermore, establishment of an efficient regeneration system from induced friable embryogenic callus is required to successfully transfer foreign gene(s) into the plant genome (Taylor et al., 1996; Raemakers et al., 1997; Lin et al., 2000a). Therefore, we focused on comparison of both vegetative and generative parts of the plant for the induction of friable embryogenic callus (FEC) and somatic embryos (SE) in order to establish a regeneration and transformation system in Alstroemeria.

\section{Materials and methods}

Seven different generative tissues (flower stalk, anther, filament, ovary, petal, ovule, stigma) were taken from field grown VV024 plants, whereas vegetative tissues (node, internode) were taken from in vitro grown VV024 plants of Alstroemeria. Surface sterilization was carried out according to Lin et al. (1997). The tissues were cultured on Murashige and Skoog (1962) medium containing $2 \mathrm{mg} / \mathrm{l}$ 2,4-dichlorophenoxyacetic acid $(2,4-\mathrm{D}), \quad 0.5 \mathrm{mg} / \mathrm{l}$ benzylaminopurine (BAP), $3 \%(\mathrm{w} / \mathrm{v})$ sucrose and $0.75 \%(\mathrm{w} / \mathrm{v})$ microagar (MS30) for callus induction. The medium was adjust to $\mathrm{pH} 6.0$ before autoclaving at $121^{\circ} \mathrm{C}$ for $20 \mathrm{~min}$. After 4 weeks of culture, induced calli were transferred to the second induction medium: MS30 supplemented with for $1 \mathrm{mg} / \mathrm{l} 2,4-\mathrm{D}$ and $0.25 \mathrm{mg} / \mathrm{l}$ BAP for growth of callus and further development into somatic embryos. Culture condition for callus induction was at $18{ }^{\circ} \mathrm{C}$ in the dark. Proliferating calli were removed 
from the explants and cultured in Petri dishes containing $25 \mathrm{ml}$ of PCA medium (Sofiari et al., 1998). For regeneration, somatic embryos were transferred to regeneration medium. That is composed of MS medium supplemented with $0.5 \mathrm{~m} / 1 \mathrm{BAP}, 2.5 \mathrm{~g} / \mathrm{l}$ Gelrite, $4 \%$ $(\mathrm{w} / \mathrm{v})$ sucrose. The culture room was maintained at $18{ }^{\circ} \mathrm{C}$ with a 16-h photoperiod of white fluorescent lamps.

\section{$\underline{\text { 3.Results }}$}

The initiation of callus formation was observed about 1 week after inoculation for anther tissue, 3 weeks for ovary tissue and 2 weeks for node and internode tissue. Other tissues showed no callus formation in the beginning of culture. A small amount of white friable calli were formed in the generative explants (Figure 1C), whereas white and yellow callus appeared in node tissues (Figure 1A). Later on, callus color in generative parts changed into a more yellowish color. Compact and friable calli were observed in these experiments (Figure 1A, B). The compact type of calli were produced in large quantities in all explants cultured (result not shown) and shown to posses a high regeneration capacity compared to friable calli (data not shown) . Regarding to callus induction, among the generative explants, the ovary tissue showed the best result with 25\%, whereas node tissue presented more promising results with $45 \%$ (Table 1). Furthermore, the formation of somatic embryos occurred only in anther, ovule and ovary of the generative parts and in all vegetative tissues after 8 weeks of culture on callus induction medium, although callus induction was obtained in all explants types tested here (Table 1). For generative parts, anther tissue showed the best result with $12.4 \%$ in somatic embryo formation (Figure 1D). Nodal tissue showed the best result with $22.5 \%$ of somatic embryo production (Figure 1E). Compact calli produced new compact calli and globular embryos on PCA medium (see materials and methods) after 8 weeks of culture. After 12 weks of culture, well-developed somatic embryos isolated from compact calli were transferred to MS medium with BAP at $0.5 \mathrm{mg} / \mathrm{l}$ for another 8 weeks in order to germinate. As a result of this, $36.5 \%$ of the somatic embryos from node-derived callus produced multiple shoots (Table 1). Some parts of embryos developed into a cotyledon (Figure 1 E).After another 4 or 6 weeks, somatic embryos generated small plantlets (Figure 1F).

\section{Discussion}

For improving a crop by using biotechnological methods, tissues with high efficiency in proliferation and regeneration must be easily obtained (Taylor et al., 1996; Raemakers et al., 1997; Lin et al., 2000a). To do this, first of all, selection of suitable explants should be conducted in terms of callus induction, proliferation and plant regeneration. Then, more detailed experiments can be tested. During our experiments, compact and friable calli were produced in all generative and vegetative parts cultured. Compact callus formed new compact callus during culture on callus induction medium. Moreover, friable callus can be obtained by subculturing compact calli on PCA medium. Furthermore, friable callus cultured on PCA medium developed via compact callus into plants. However, friable callus showed less regenerability than that of compact callus, although friable callus has a possibility to be used in transfromation experiments due to its superior proliferation rate (Van Schaik, 1998; Lin et al., 2000b). So far, both compact and friable calli have maintained for more than 1 year on BA-containing medium without losing their capacities to regenerate plants. In summary, nodal segments have proven to be a considerable source for further application to transformation, due to their easy accessibility, high regeneration and callus induction capacity in these experiments. Therefore, vegetative tissues such as nodes can be used in a transformation system as starting material. To achieve this, more research on several factors in the establishment of high efficiency regeneration protocols of FEC and compact callus will be performed in the future. 


\section{$\underline{\text { References }}$}

Gonzalez-Benito, M.E. and Alderson, P. G. 1992. Callus induction and plant regeneration in Alstroemeria. Jour. of Exp. Bot. 247:205-211.

Hutchinson, M. J., Senaratna, T. Tsujita, J. M. and Saxena, P. K., 1997. Somatic embryogenesis in liquid cultures of a tetraploid Alstroemeria. Plant Cell Tissue Organ Culture 47:293-297.

Lin, H.S., De Jeu, M.J. and Jacobsen, E. 1997. Direct shoot regeneration from excised leaf explants of in vitro grown seedlings of Alstroemeria L. Plant Cell Reports 16: 770-774.

Lin, H.S., van der Toorn, C., Raemakers, K.J.J.M., Visser, R.G.F., De Jeu M.J. and Jacobsen, E. 2000a. Development of a plant regeneration system based on friable embryogenic callus in the ornamental Alstroemeria. Plant Cell Reports 19: 529-534.

Lin, H.S., van der Toorn, C., Raemakers, K.J.J.M., Visser, R.G.F., De Jeu, M.J. and Jacobsen, E. 2000b. Genetic transformation of Alstroemeria using particle bombardment. Molecular Breeding. (in press).

Murashige, T. and Skoog, F. 1962. A revised medium for rapid growth and bioassays with tobacco tissue cultures. Physiol. Plant. 15:473-497

Raemakers, C.J.J.M., Sofiari, E. Jacobsen, E. and Visser, R.G.F. 1997. Regeneration and transformation of cassava. Euphytica 96:153-161

Sofiari, E., Raemakers, K.J.J.M., Bergervoet, J.E.M., Jacobsen, E. and Visser, R.G..F. 1998. Plant regeneration from protoplasts isolated from friable embryogenic callus of cassava. Plant Cell Reports 18: 159-165.

Taylor, N.J., Edwards, M., Kiernan, R.J., Davey, C.D.M., Blakesley, D. and Henshaw, G.G. 1996. Development of friable embryogenic callus and embryogenic suspension culture systems in cassava (Manihot esculenta Crantz). Nature Biotechnology 14:726730.

Van SchaikPosthuma, A., De Jeu, M.J. and Jacobsen, E. 1996. Plant regeneration through somatic embryogenesis from callus induced on immature embryos of Alstroemeria spp. L. Plant Cell Reports 15:377-380.

Van Schaik,C.E. 1998. Regeneration and transformation of Alstroemeria L. PhD thesis, Agricultural University Wageningen.

Ziv, M., Kanterovitz, R. and Halevy, A. H., 1973. Vegetative propagation of Alstroemeria in vitro. Sci. Hort. 1:271-277. 


\section{Tables}

Table 1. Comparison of the in vitro response between generative and vegetative parts in VV024 of Alstroemeria.

\begin{tabular}{lcccccc}
\hline $\begin{array}{l}\text { Explant } \\
\text { Type }\end{array}$ & $\begin{array}{c}\text { No. of } \\
\text { Explant }\end{array}$ & $\begin{array}{c}\text { Percentage of } \\
\text { Explants } \\
\text { with callus* }\end{array}$ & $\begin{array}{c}\text { Percentage of } \\
\text { Explants } \\
\text { with somatic } \\
\text { Embryos* }\end{array}$ & $\begin{array}{c}\text { Percentage } \\
\text { of somatic } \\
\text { Embryos } \\
\text { with shoots** }\end{array}$ & $\begin{array}{c}\text { Level of } \\
\text { Browning*** }\end{array}$ & $\begin{array}{c}\text { Color } \\
\text { of } \\
\text { Formed } \\
\text { Callus* }\end{array}$ \\
\hline Node & 120 & 45.0 & 22.5 & 36.5 & ++ & Yellow \\
Internode & 120 & 30.0 & 8.3 & 15.0 & +++ & White \\
Anther & 210 & 21.9 & 12.4 & 0.0 & ++ & Yellow \\
Ovule & 100 & 16.0 & 3.0 & 0.0 & +++ & Yellow \\
Petal & 125 & 2.4 & 0.0 & 0.0 & +++ & White \\
Ovary & 200 & 25.0 & 4.5 & 0.5 & ++ & White \\
Flower stalk & 100 & 3.0 & 0.0 & 0.0 & +++ & White \\
Stigma & 60 & 5.0 & 0.0 & 0.0 & ++ & White \\
Filament & 250 & 0.8 & 0.0 & 0.0 & +++ & White \\
\hline
\end{tabular}

*: These data were collected after 8 weeks of culture on callus induction medium $* *$ : These data were collected after 12 weeks of culture on regeneration medium ***: +++ Severe browning ++ normal browning + weak browning

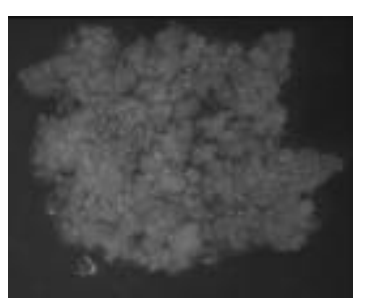

A

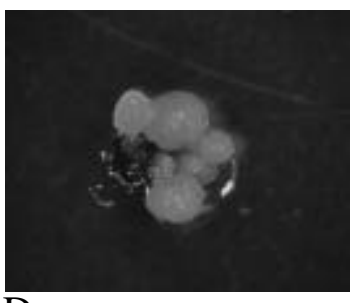

D

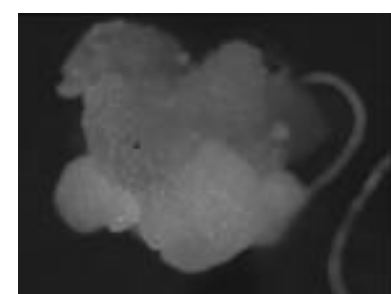

B

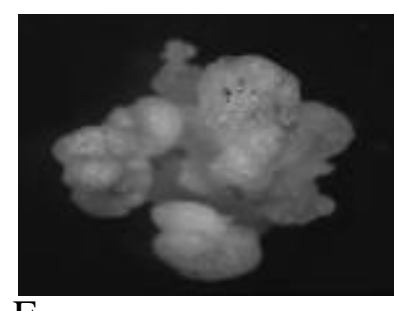

$\mathrm{E}$

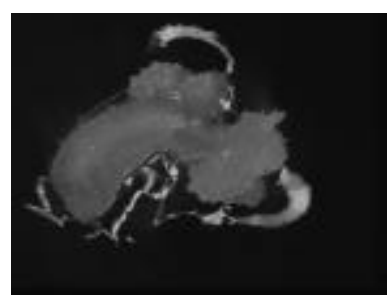

$\mathrm{C}$

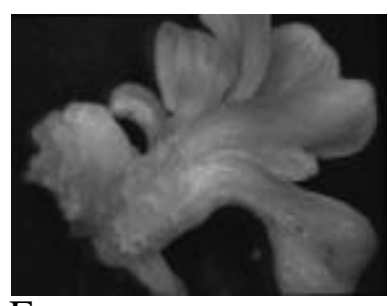

Fig.1. Different stages of regeneration process of calli from all vegetative and generative in VV024 of Alstroemeria

A: Friable embryogenic clump from node B: Compact callus from node

C: Friable calli on ovule D: Embryo structures from anther tissue

E: Germination of somatic embryos from node F: Plant regeneration 